\section{Pengaruh Politik Uang Terhadap Partisipasi Pemilih Pemilukada Pemilihan Bupati dan Wakil Bupati Wajo Tahun 2018}

\section{Hardianto Hawing ${ }^{1}$, Besse Nurul Fadillah $^{2}$, Hafiz Elfiansya Parawu ${ }^{3}$}

1) Program Studi Ilmu Pemerintahan Fakultas Ilmu Sosial dan Ilmu Politik Universitas Muhammadiyah Makassar

2) Program Studi Ilmu Pemerintahan Fakultas Ilmu Sosial dan Ilmu Politik Universitas Muhammadiyah Makassar

3) Program Studi Ilmu Pemerintahan Fakultas Ilmu Sosial dan Ilmu Politik Universitas Muhammadiyah Makassar

Korespondensi Penulis. E-mail: hardiantohawing@gmail.com

\begin{abstract}
Abstrak
Penelitian ini bertujuan untuk mengetahui Politik Uang dan Partisipasi Pemilih Pemula pada Pemilihan Bupati dan Wakil Bupati Wajo tahun 2018. Jenis penelitian menggunakan pendekatan kuantitatif. Data yang diolah hasil penyebaran instrumen berupa kusioner terhadap 98 responden yang menjadi sampel penelitian dengan menggunakan teknik purposive sampling. Data yang diperoleh, kemudian dianalisis menggunakan analisis regresi linier sederhana secara parsail dan simultan. Hasil penelitian analisis deskriktif menujukkan bahwa variabel politik uang $(\mathrm{X})$ berdasarkan indicator pemberian uang, pemberian barang, pemberian janji/imingiming masuk dalam kategori cukup berpengaruh dengan rata-rata skor 2,89 dan variabel partisipasi politik (Y) berdasarkan indikator memberikan suara, menghadiri rapat umum, menjadi anggota suatu partai/ kelompok kepentingan, mengadakan hubungan kontak dengan pemerintah/anggota parlemen masuk dalam kategori cukup berpengaruh dengan rata-rata skor 2,78. Berdasarkan hasil uji regresi linier sederhana menunjukkkan bahwa variabel politik uang berpengaruh sebesar 53\% terhadap partisiapsi politik
\end{abstract}

pada Pemilihan Bupati dan Wakil Bupati Tahun 2018.

Kata Kunci: Politik Uang, Partispasi Politik, Pemilihan Umum.

The Iinfluence Of Money Politics On Election Participation In The Election of Regent And Vice Regent Of Wajo In 2018

\section{Abstract}

This study aims to determine the Politics of Money and Participation of Beginner Voters in the Election of Regent and Deputy Regent of Wajo in 2018. This type of research uses a quantitative approach. The data that is processed is the result of the distribution of instruments in the form of questionnaires to 98 respondents who became the research sample using purposive sampling technique. The data obtained, then analyzed using simple linear regression analysis in parsail and simultaneously. The results of descriptive analysis showed that the money politics variable $(X)$ based on the indicators of giving money, giving goods, giving promises / lures was in the quite influential category with an average score of 2.89 and the political participation variable $(Y)$ based on the indicators of voting. attending a general meeting, being a member of a party / interest group, making contact with the government / parliamentarians are in the quite influential category with an average score of 2.78. Based on the results of the simple linear regression test, it shows that the variable money politics has an effect on 53\% of political participation in the 2018 Regent and Deputy Regent Elections.

Keywords: Money Politics, Political Participation, General Election. 


\section{A. PENDAHULUAN}

Pemilu (Pemilihan Umum) adalah wujud nyata dari implementasi demokrasi walaupun demokrasi tidak sama dengan pemilihan umum. Namun, pemilihan umum merupakan pranata terpenting dalam tiap negara demokrasi, terlebih lagi bagi negara yang berbentuk republik seperti Indonesia (Fadjar, 2013). Demokrasi merupakan sistem pemerintahan yang digunakan oleh Indonesia sejak kemerdekaan Indonesia dicapai. Sistem pemerintahan tersebut berasal dari rakyat, oleh rakyat, dan untuk rakyat. Meskipun telah menerapkan sistem pemerintahan demokrasi sejak lama, sistem pemerintahan yang menetapkan rakyat sebagai pemegang kedaulatan tertinggi ini masih dirasa belum berkembang dengan baik sampai saat ini.

Pemilih pemula merupakan salah satu segmen yang memang menjanjikan secara kuantitas dalam pemilu. Termasuk pada Pemilukada Wajo tahun 2018. Berdasarkan data KPU Kabupaten Wajo, jumlah pemilih pemula yang terdaftar sebanyak 6.396 jiwa. Dengan jumlahnya yang cukup besar menjadi ladang perebutan bagi yang berkepentingan dalam kontestasi 5 (lima) tahunan ini. Salah satu kabupaten yang melakukan pesta demokrasi pada Pemilukada 2018 adalah Kabupaten Wajo yang berada di Provinsi Sulawesi Selatan. Kabupaten Wajo terdiri dari 14 Kecamatan, 142 Desa, dan 48 Kelurahan, dengan jumlah tempat pemungutan suara (TPS) Pemilukada 2018 mencapai 902 TPS.

Pada Pemilukada ini di ikuti dua (2) pasangan kandidat, yakni H. Amran
Mahmud , S.Sos., M.Si - H. Amran, S.E (Pammase) dan H. Baso Rahmanuddin, M.M,. M.Kes, - KH Anwar Sadat Bin Abdul Malik, LC., M.A (Barakka). Pada Pemilukada ini, Daftar Pemilih Tetap (DPT) di Kabupaten Wajo berjumlah 270.192 orang yang terdiri dari pemilih laki-laki sebanyak 127.419 dan pemilih perempuan sebanyak 142.733. Pasangan calon nomor urut 1 (Pammase) meraih suara terbanyak yaitu 104.384 dengan persentase 57,91 persen, sedangkan pasangan calon nomor urut 2 (Barakka) memperoleh 75.876 suara atau persentase 42,09 persen. Jumlah suara sah 180.255 , suara tidak sah 2.589, total seluruh suara sah dan tidak sah 182.908 atau dengan persentase $67 \%$ dari jumlah DPT.

Pemilukada yang dilaksanakan pada Juni 2018 ini, banyak diwarnai kecurangan yang salah satunya adalah politik uang. Berbagai cara dilakukan oleh kandidat untuk mendulang suara dengan menggunakan politik uang. Berawal untuk maju sebagai kontestan calon kandidat, praktek politik uang sudah terindikasi terjadi. Secara umum, pengertian politik uang dalam tulisan ini adalah terkait upaya mempengaruhi massa pemilu dengan imbalan materi berupa pemberian langsung uang tunai, pemberian bantuan/sumbangan barang, pemberian bahan pokok berupa sembako, dan memberi dan menjanjikan iming-iming 'sesuatu' untuk mendapatkan keuntungan politik, atau juga disebut istilah politik transaksional. Pembagian uang secara langsung dilakukan oleh tim sukses $\mathrm{k}$ epada pemilih pada masa tenang. Praktek ini dilakukan saat minus seminggu dan malam pencoblosan yang 
juga disebut 'serangan fajar' atau 'operasi malam' yang dilakukan secara 'door to door or man to man'. Praktek ini semata-mata dengan tujuan agar pemilih akan memilih kandidat tersebut. Tetapi politik uang tidak hanya dilakukan secara konvensional, tapi juga berupa janji-janji politik. Praktek ini lebih bersifat jangka panjang dengan menyalahgunakan kebijakan programatik, seperti bantuan sosial atau hibah maupun dana proyek untuk kepentingan pendukung baik secara kelompok maupun secara individu.

Dalam perjalanannya bahwa politik uang ini merupakan tindakan membagi-bagikan uang, barang dan jasa sudah mengalami pembiasan makna. Sedangkan batasan pelaku politik menurut Ismawan adalah orang yang memberi uang politik baik kandidat, pendukung atau tim sukses dan penerima uang politik dalam bentuk apapun. Politik uang dilakukan dengan sadar oleh pihak-pihak yang melakukan politik uang. Politik uang masih saja marak terjadi dilingkungan pemilu Kabupaten Wajo. Terutama mengenai seberapa jauh pengaruh dari politik uang khususnya untuk pemilih pemula yang masih belum mengetahui tentang dinamika politik. Agar dapat mengantisipasi terjadinya kecurangan salah satunya politik uang maka pemerintah terus melakukan sosialisasi kepada para pemuda dan pemilih pemula.

Fenomena politik uang yang sudah masuk dan menjadi hal lazim terjadi di daerah tentunya menarik untuk diteliti. Hasil wawancara yang dilakukan peneliti kepada beberapa informan atau masyarakat mengatakan bahwa dalam pemilihan Bupati dan Wakil Bupati tahun 2018 cenderung mendapatkan interpensi oleh tim sukses calon kandidat dengan menerapkan pendekatan politik uang (money politic) yang lebih dari puluhan pemilih pemula mendapatkan insentif berupa uang langsung agar calon yang diajukan itu bisa memenangkan pemilu. Bukan hanya sebenarnya pemilih pemula saja akan tetapi hampir semua lapisan masyarakat mendapatkan serangan politik uang.

\section{B. TEORI (Literature Review)}

Budiardjo (2008), menjelaskan bahwa dewasa ini definisi mengenai politik yang sangat normatif itu telah terdesak oleh definisi-definisi lain yang lebih menekankan pada upaya untuk mencapai masyarakat yang baik, seperti kekuasaan, pembuatan keputusan, kebijakan, alokasi nilai, dan sebagainya. Partisipasi politik memiliki peran penting dalam proses pemilihan umum pesta demokrasi. Partisipasi politik adalah kegiatan-kegiatan sukarela dari warga masyarakat melalui mana mereka mengambil bagian dalam proses pemilihan penguasa, secara langsung atau tidak langsung, dalam proses pembentukan kebijakan umum (McClosky, 2008). Budiarjo dalam partisipasi dan partai politik (1998) mengatakan bahwa partisipasi politik adalah kegiatan seseorang atau sekelompok orang ikut serta secara aktif dalam kehidupan politik, yaitu dengan jalan memilih pimpinan negara dan secara lngsung ataupun tidak langsung, mempengaruhi kebijakan pemerintah (public policy) kegiatan ini mencakup tindakan seperti memberikan suara 
dalam pemilihan umum, menghadiri rapat umum, menjadi anggota suatu partai, atau kelompok kepentingan, mengadakan hubungan kontak dengan pejabat pemerintah atau anggota parlemen dan sebagainya. Dalam pemilu, pemberian suara merupakan salah satu bentuk dari sekian bentuk partisipasi politik dalam berdemokrasi. Pemberian suara menjadi ukuran paling dasar dalam politik konvensional. Dalam partisipasi pemilih, salah satu basis suara diperebutkan dalam disetiap tingkatan pemilihan adalah basis suara pemilih pemula.

Pemilih pemula merupakan pemilih yang baru pertama kali memilih karena usia mereka baru memasuki usia pemilih yaitu 17 hingga 21 tahun. UU No. 7 tahun 2017 tentang pemilu memberikan jaminan bagi pemilih pemula yang genap berusia 17 tahun guna menyalurkan hak pilihnya pada pemilu. Menurut Undang-Undang No. 10 tahun 2008 dalam Bab IV pasal 19 ayat 1 dan 2 serta pasal 20 menyebutkan bahwa yang dimaksud dengan pemilih pemula adalah warga Indonesia yang pada hari pemilihan atau pemungutan suara adalah Warga Negara Indonesia yang sudah genap berusia 17 tahun dan atau lebih atau sudah/pernah kawin yang mempunyai hak pilih, dan sebelumnya belum yang terkuat bagi rakyat untuk berpartisipasi didalam sistem demokrasi perwakilan modern.

\section{METODE}

Waktu penelitian ini dilakukan sejak bulan Agustus hingga bulan September 2020. Tipe penelitian menggunakan metode jenis penelitian deskriptif dengan pendekatan kuantitatif. Populasi penelitian ini adalah 6.396 pemilih pemula pada Pemilukada Tahun 2018 di Kabupaten Wajo. Teknik penarikan sampel menggunakan Purposive Sampling yaitu salah satu teknik sampel non random dengan jumlah 98 responden. Sumber data menggunakan kusioner yang didukung oleh observasi dan dokumentasi. Teknik penyajian data dilakukan dengan metode deskriptif yang diajukan dalam bentuk tabulasi data. Dengan metode analisis regresi linear sederhana dengan bantuan program SPSS 20 hal ini, dirumuskan untuk melihat pengaruh antar variabel dan indikator dengan akurasi yang tinggi melalui proses uji validasi dan uji reliabilitas data dan analisis data dalam bentuk kalimat, menarik kesimpulan dari gambar/tabel yang disajikan. Teknik analisis data menggunakan analisis statistik deskriptif yang mendeskripsikan data yang tersaji dengan penyajikan data dengan tabel dan diagram. Uji kualitas data dengan hasil uji validasi dan reliabilitas serta regresi linear sederhana secara parsial dan simultan. 
D. HASIL DAN PEMBAHASAN

\section{Hasil Uji Validitas dan} Reliabilitas Data

Pada analisis SPSS untuk melihat valid tidaknya item pertanyaan dilakukan dengan instrumen penelitian jika nilai $r_{\text {hitung }}$ (nilai pearson correlation) $>r_{\text {tabel }}$ (nilai $\beta$ tabel untuk 98 responden $=0,198$ ) dikatakan valid. Namun jika dikatakan tidak valid maka nilai $r_{\text {hitung(nilai Sig. (2-tailed)) }}$ $<r_{\text {kritis }}(=0.05)$. Berikut adalah hasil perhitungan SPSS 12 item pernyataan dari variabel politik uang $(\mathrm{X})$ :

Tabel 1. Hasil Uji Validitas Instrumen Penelitian Variabel Politik Uang (X)

\begin{tabular}{|l|l|l|l|l|}
\hline Variabel & $\begin{array}{l}\text { Item } \\
\text { Pernyataan }\end{array}$ & $\begin{array}{l}\text { Corrected } \\
\text { item total } \\
\text { correlation }\end{array}$ & $\begin{array}{l}\mathrm{R} \text { Tabel } \\
\mathrm{n}=94 \text { taraf 5\% }\end{array}$ & Keterangan \\
\hline \multirow{5}{*}{$\begin{array}{l}\text { Politik } \\
\text { Ung }\end{array}$} & $\mathbf{X} 1$ & 0.774 & 0,198 & Valid \\
\cline { 2 - 5 } & $\mathrm{X} 2$ & 0.757 & 0,198 & Valid \\
\cline { 2 - 5 } & $\mathrm{X} 3$ & 0,722 & 0,198 & Valid \\
\cline { 2 - 5 } & $\mathrm{X} 4$ & 0,738 & 0,198 & Valid \\
\cline { 2 - 5 } & $\mathrm{X} 5$ & 0,748 & 0,198 & Valid \\
\cline { 2 - 5 } & $\mathrm{X} 6$ & 0,731 & 0,198 & Valid \\
\cline { 2 - 5 } & $\mathrm{X} 8$ & 0,796 & 0,198 & Valid \\
\cline { 2 - 5 } & $\mathrm{X} 9$ & 0,709 & 0,198 & Valid \\
\cline { 2 - 5 } & $\mathrm{X} 10$ & 0,647 & 0,198 & Valid \\
\cline { 2 - 5 } & $\mathrm{X} 11$ & 0,697 & 0,198 & Valid \\
\cline { 2 - 5 } & $\mathrm{X} 12$ & 0,624 & 0,198 & Valid \\
\hline
\end{tabular}

Sumber: Data Primer Diolah, 2020

Dari kolom Pearson Correlation pada tabel di atas terlihat bahwa semua item permyataan lebih besar dari 0,198 dengan demikian dapat disimpulkan bahwa semua pernyataan pada variabel politik uang (X) Valid. Dari kolom Pearson Correlation pada tabel di atas terlihat bahwa semua item permyataan lebih besar dari 0,198 dengan demikian dapat disimpulkan bahwa semua pernyataan pada variabel partisipasi politik (Y) Valid. Untuk hasil analisis validasi variabel partisipasi politik $(\mathrm{Y})$ dapat dilihat pada tabel 2 . 
Vol.2 No.2 Desember 2020

Tabel 2. hasil analisis validasi variabel partisipasi politik (Y)

\begin{tabular}{|l|l|l|l|l|}
\hline \multirow{4}{*}{ Variabel } & Item & $\begin{array}{l}\text { Corrected } \\
\text { item total } \\
\text { Pernyataan }\end{array}$ & $\begin{array}{l}\mathrm{R} \text { Tabel } \\
\text { correlation }\end{array}$ & Keterangan \\
\hline \multirow{5}{*}{ partisipasi 5\% } & Y1 & 0.315 & 0,198 & Valid \\
\cline { 2 - 5 } & Y2 & 0.424 & 0,198 & Valid \\
\cline { 2 - 5 } & Y3 & 0,639 & 0,198 & Valid \\
\cline { 2 - 5 } & Y4 & 0,633 & 0,198 & Valid \\
\cline { 2 - 5 } & Y6 & 0,570 & 0,198 & Valid \\
\cline { 2 - 5 } & Y7 & 0,637 & 0,198 & Valid \\
\cline { 2 - 5 } & $\mathrm{X} 8$ & 0,706 & 0,198 & Valid \\
\cline { 2 - 5 } & $\mathrm{X} 9$ & 0,678 & 0,198 & Valid \\
\cline { 2 - 5 } & $\mathrm{X} 10$ & 0,725 & 0,198 & Valid \\
\cline { 2 - 5 } & $\mathrm{X} 11$ & 0,702 & 0,198 & Valid \\
\cline { 2 - 5 } & $\mathrm{X} 12$ & 0,677 & 0,198 & Valid \\
\hline
\end{tabular}

Sumber: Data Primer Diolah, 2020

Lebih lanjut, reliabitias adalah sejauh mana hasil pengukuran dengan menggunakan objek yang sama akan menghasilkan data yang sama. Setelah didapat reliabilitas Instrumen $(\mathrm{r}-$ hitung), maka nilai tersebut dibandingkan dengan r-tabel yang sesuai dengan jumlah responden dan taraf nyata.Bila r-hitung > r-tabel, maka instrument tersebut dikatakan reliable. Untuk uji reliabilitas digunakan teknik Alpha Cronbach yaitu sebesar 0,70. Jika nilai r-hitung > dari 0,70 maka item tersebut dinyatakan valid. Hasil uji realibiltas dapat dilihat pada tabel 3.

Tabel 3. Hasil uji realibiltas

\begin{tabular}{|l|l|l|l|l|}
\hline No. & Variabel & $\begin{array}{l}\text { Cronbach's Alpha } \\
\text { Based on Stndardizes } \\
\text { Items }\end{array}$ & $\begin{array}{l}\text { Standar } \\
\text { Reliabilitas }\end{array}$ & Keterangan \\
\hline 1. & $\begin{array}{l}\text { Politik } \\
\text { Uang }\end{array}$ & 0,912 & 0.70 & Reliabel \\
\hline 2. & $\begin{array}{l}\text { Partisipasi } \\
\text { Politik }\end{array}$ & 0,852 & 0.70 & Reliabel \\
\hline
\end{tabular}

Sumber: Data Primer Diolah, 2020 
Vol.2 No.2 Desember 2020

Berdasarkan data tabel diatas

bahwa variabel indenpenden dan menunjukkan angka-angka dari nilai cronbachs Alpha(a) pada seluruh variable dalam penelitian ini, semuannya menunjukkan besaran di atas nilai 0.70. Hal ini menunjukkan dependen adalah reliable dan dapat disimpulkan bahwa pernyataan kusioner responden menunjukkan kehandalan dalam mengukur variablevariabel dalam model penelitian.

Tabel 4. Hasil Analisis Deskriptif Rekapitulasi Analisis Deskriptif Variabel Politik Uang (X)

\begin{tabular}{|l|l|l|}
\hline No. & Indikator Analisis Variabel Politik Uang (x) & Rata-rata Skor \\
\hline 1. & Pemberian Uang & 2,99 \\
\hline 2. & Pemberian Barang & 2,87 \\
\hline 3. & Pemberian janji & 2,82 \\
\hline Rata-rata & 2,89 \\
\hline
\end{tabular}

Sumber: Data Primer Diolah, 2020

Berdasarkan tabel di atas, hasil rekapitulasi analisis variabel Politik Uang pada Pemilihan Bupati dan Wakil Bupati Wajo Tahun 2018 bahwa Hasil analisis deskriptif untuk variabel Politik
Uang berdasarkan indikator pemberian uang, pemberian barang, pemberian janji memperoleh hasil sebesar 2,89 yang dikategorikan cukup berpengaruh.

Tabel 5. Rekapitulasi Analisis Deskriptif Variabel Partisipasi Politik (Y)

\begin{tabular}{|l|l|l|}
\hline No. & Indikator Analisis Variabel Partisipasi Politik (Y) & Rata-rata Skor \\
\hline 1. & Memberikan suara (mencoblos) & 2,98 \\
\hline 2. & Menghadiri rapat umum partai/kelompok & 2,83 \\
\hline 3. & $\begin{array}{l}\text { Menjadi anggota suatu kejantingan } \\
\text { kepentingat }\end{array}$ & 2,61 \\
\hline 4. & $\begin{array}{l}\text { Mengadakan hubungan kontak dengan pejabat } \\
\text { pemerintah atau anggota parlemen }\end{array}$ & 2,78 \\
\hline \multicolumn{2}{|l|}{ Rata-rata } & \\
\hline
\end{tabular}

Sumber: Data Primer Diolah, 2020

Berdasarkan tabel di atas, hasil rekapitulasi analisis variabel Partisipasi Politik pada Pemilihan Bupati dan Wakil Bupati Wajo Tahun 2018 bahwa Hasil analisis deskriptif untuk variabel Partisipasi Politik berdasarkan indikator memberikan suara (mencoblos), menghadiri rapat umum, menjadi anggota suatu partai/kelompok kepentingan, mengadakan hubungan kontak dengan pejabat pemerintah atau anggota palemen memperoleh hasil sebesar 2,78 yang dikategorikan cukup berpengaruh. 
a. Analisis Regresi Linier Sederhana Secara Parsial

1) Pengaruh Pemberian Uang (X1) Taerhadap Partisispasi Politik (Y) dengan persentase $46 \%$ atau $\mathrm{R}$ Square 0,46.

2) Pengaruh Pemberian Barang (X2) Terhadap Partisipasi Politik (Y) dengan persentase $52 \%$ atau dengan R Square 0,52.

3) Pengaruh Pemberian Janji (X3) Terhadap Partisipasi Politik (Y) dengan persentase $6 \%$ atau dengan $\mathrm{R}$ Square 0,006.

Berdasarkan uraian di atas, dapat diketahui besar pengaruh variabel $\mathrm{X}$ terhadap variabel $Y$, dimana dari tabel tersebut dapat terlihat variabel yang memiliki pengaruh besar dibandingkan dengan variabel lainnya, variabel yang memiliki pengaruh yang paling besar adalah variabel $\mathrm{X} 2$ yang memiliki nilai $\mathrm{R}$ square sebesar 0,52 dengan persentase $52 \%$.

\section{b. Regresi Linear Sederhana Secara Simultan}

Untuk mengetahui apakah ada pengaruh antara variabel Politik Uang (X) dengan Partisipasi Politik (Y), dapat juga dilakukan uji regresi linear secara simultan dengan menggunakan SPSS versi 21. Output bagian pertama (Variabel Entered/Removed), pada variabel yang dimasukkan adalah variabel politik uang sebagai variabel Independent dan partisipasi politik sebagai variabel Dependen.

Tabel 5. Model Summary

\begin{tabular}{|l|l|l|l|l|}
\hline Model & $\mathrm{R}$ & R Square & Adjusted R Square & Std. Error of the Estimate \\
\hline 1 & $.230^{\mathrm{a}}$ & .053 & .043 & 5.67738 \\
\hline
\end{tabular}

Sumber: Data Primer Diolah 2020.

Berdasarkan tabel tersebut, dapat diketahui nilai $\mathrm{R}^{2}$ (Adjusted $R$ Square) dari model regresi digunakan untuk mengetahui seberapa besar kemampuan variabel bebas (Independent) dalam menerangkan variabel terkait (dependent). Dari tabel di atas diketahui bahwa $\mathrm{R}^{2}$ sebesar 0,53 hal ini berarti $53 \%$ yang menunjukkan politik uang mempengaruhi partisipasi politik, dan sisanya dipengaruhi oleh variabel lain yang belum diteliti dalam penelitian ini.

Uji $\mathrm{F}$ digunakan untuk mengetahui variabel politik uang bersama-sama bepengaruh variabel partisipasi politik, dengan hipotesis sebagai berikut:

$\mathrm{H} 0=$ Tidak ada pengaruh politik uang dengan partisipasi politik pada Pemilihan Umum Kepala Daerah Kabupaten Wajo.

$\mathrm{Ha}=$ Terdapat pengaruh yang signifikan politik uang dengan partisipasi politik pada Pemilihan Umum Kepala Daerah Kabupaten Wajo.

Berdasarkan tabel uji $\mathrm{F}$ dapat diliht bahwa dalam pengujian regresi mnunjukkan hasil $\mathrm{F}$ hitung sebesar 5,339 dengan signifikan 0,023 yang lebih kecil dari 0,05 dimana nilai $F$ hitung lebih besar dari F tabelnya, 
Vol.2 No.2 Desember 2020

berarti variabel politik uang (X) berpengaruh terhadap partisipasi politik (Y)

\section{Politik Uang (X)}

Politik uang merupakan upaya mempengaruhi massa pemilu dengan imbalan materi yang secara umum dapat disebut politik transaksional. Indikator-indikator politik uang dalam penelitian ini sebagai berikut:

a) Pemberian uang. Indikator pemberian uang mencakup 3 hal yaitu pemberian uang melalui momentum kampanye, dan pemberian uang secara langsung dengan mendatangi rumah calon pemilih, pemberian uang dengan besaran tertentu yang telah disetujui dalam proposal. Berdasarkan hasil penelitian menunjukkan bahwa ketiga indikator tersebut masuk dalam kategori berpengaruh. Hal ini menunjukkan bahwa pemberian uang pada pemilihan kepala daerah Kabupaten Wajo dapat dikategorikan berpengaruh dalam meningkatkan partisipasi politik.

b) Pemberian Barang. Indikator pemberian barang mencakup 6 hal yaitu memberikan bantuan sembako, menjadikan masyarakat menengah kebawah sebagai target pemberian bantuan, sumbangan atau bantuan diberikan secara berkala, memberikan hadiah dalam bentuk barang, memberika barang sesuai kebutuhan dan pemberian atribut kampanye. Berdasarkan hasil penelitian bahwa keenam indikator tersebut masuk dalam kategori berpengaruh. Hal ini menunjukkan bahwa pemberian barang pada pemilihan kepala daerah Kabupaten Wajo dapat dikategorikan berpengaruh dalam meningkatkan partisipasi politik.

c) Pemberian Janji. Indikator pemberian janji mencakup tiga hal yaitu menjanjika suatu jabatan atau posisi, menjanjikan beaiswa lanjut pendidikan dan berpengaruhan fasilitas umum. Berdasarkan hasil peneltian bahwa ketiga indikator tersebut masuk dalam kategori cukup berpengaruh. Hal ini meunjukkan bahwa pemberian janji pada pemilihan kepala daerah Kabupaten Wajo dapat dikategorikan cukup berpengaruh dalam meningkatkan partisipasi poitik.

Secara teori dapat dipahami bahwa politik uang dalam arena perpolitikan dengan sistem demokrasi, pemberian suara oleh pemilu pemula terdapat korelasi akan adanya imbalan seperti halnya pemberian uang, barang, ataupun janji-janji politik. Hal didukung dengan terbukti adanya pengaruh politik uang terhadap partisipasi pemilih pemula. Dai hasil penelitian, terkonfirmasi bahwa terdapat beberapa pemilih pemula di suatu daerah menentukan pilihannya berdasarkan imbalan yang diterima. Dengan hal tersebut menjelaskan adanya pengaruh sumber daya politik uang dalam kanca arena kontestasi politik. Jadi teori dari Ismawan yang mengatakan bahwa politik uang adalah upaya mempengaruhi perilaku orang dengan menggunakan imbalan tertentu seperti pemberian uang, barang atau imingiming sesuatu kepada massa secara berkelompok atau individual untuk 
mendapatkan keuntungan politis terbukti sejalan dengan hasil temuan di lapangan.

\section{Partisipasi Politik (Y)}

Berdasarkan penilaian partisipiasi politik terhadap 4 indikator yang meliputi pemberian hak suara, menghadiri rapat umum, menjadi anggota partai dan mengadakan hubungan kontak pemerintah dijelaskan masing-masing indikator sebagai berikut:

a) Pemberian hak suara. Berdasarkan hasil penelitian, indikator pemberian hak suara dalam penelitian ini terdapat 3 hal yaitu memberikan hak suara, melakukan pencoblosan sesuai dengan waktu yang ditentukan, dan mengiktui rencana yang telah diatur bersama kandidat masuk dalam kategori cukup berpengaruh. Hal ini menunjukkan bahwa pemberian hak suara pada pelaksanaan pemilihan kepala daerah kabupaten wajo dapat dikategorikan cukup berpengaruh.

b) Menghadiri rapat umum. Indikator menghadiri rapat umum dalam penelitian ini mencakup 3 hal yaitu menghadiri rapat umum, aktif dalam memberikan tanggapan pada saat rapat, dan ikut melakukan serta dalam melakukan sosialisasi pemilu. Berdasarkan hasil penelitian bahwa ketiga indikator tersebut masuk dalam kategori cukup berpengaruh. Hal ini menunjukkan bahwa dengan menhadiri rapat umum pemilihan kepala daerah kabupaten wajo dapat dikategorikan cukup berpengaruh. c) Menjadi anggota partai. Indikator menjadi anggota partai dalam penelitian ini mencakup 3 hal yaitu menjadi anggota suatu partai kelompok tim sukses atau kandidat, menjadi anggota pasif suatu partai karena status pemilih pemula, dan ikut memasang atribut kandidat seperti baliho, benner dan sebagainya. Berdasarkan hasil penelitian bahwa ketiga indikator tersebut masuk dalam kategori cukup berpengaruh. Hal ini menunjukkan bahwa dengan menjadi anggota partai pada pemilihan kepala daerah Kabupaten Wajo dapat dikategorikan cukup berpengaruh.

d) Mengadakan hubungan kontak pemerintah maupun anggota parlemen. Indikator mengadakan hubungan kontak pemerintah mencakup 3 hal yaitu mengadakan hubungan kontak pejabat atau parlemen, memiliki tugas dan jabatan sebagai anggota dalam hubungan kontak pemerintah atau parlemen dan pemilih pemula mambangun komunikasi yang berpengaruh kepada tim sukses atau kandidat. Berdasarkan hasil penelitian menunjukkan bahwa ketiga indikator tersebut masuk dalam kategori cukup berpengaruh. Hal ini menunjukkan bahwa dengan mengadakan hubungan kontak pemerintah pada pemilihan kepala daerah Kabupaten Wajo dapat dikategorikan cukup berpengaruh.

Dalam penelitian ini, partisipasi politik menurut Mariam Budiardjo adalah kegiatan seseorang atau sekelompok orang ikut sera secara aktif 
Vol.2 No.2 Desember 2020

dalam kehidupan politik seperti memberikan suara dalam pemilu, menghadiri rapat umum, menjadi anggota partai politik, serta mengadakan hubungan kontak dengan pejabat pemerintah atau parlemen menunjukkan secara bersama-sama mempengaruhi partisipasi pemilih pemula dan sejalan dengan hasil temuan di lapangan, meskipun pada akhirnya penelitian ini menemukan adanya kecenderungan partisipasi pemilih pemula ditentukan oleh praktik-praktik politik uang.

\section{Pengaruh Secara Parsial Politik} Uang terhadap Partisipasi Politik pada Pemilihan Kepala Daerah Kabupaten Wajo

Pengaruh pemberian uang (X1) terhadap partisipasi politik (Y). Berdasarkan hasil penelitian uji koefisien determinasi menggunakan uji parsial, diperoleh hasil bahwa pemberian uang (X1) memiliki pengaruh siginfikan terhadap partisipasi politik (Y). hal ini dibuktikan bahwa dari nilai koefisien determinasi diketahui bawah $\mathrm{R}^{2}$ sebesar 0,46 yang artinya $46 \%$ menunjukkan bahwa pemberian uang berpengaruh terhadap partisipasi politik pada pada pemilihan kepala daerah Kabupaten Wajo.

a) Pengaruh pemberian barang (X2) terhadap partisipasi politik (Y). Berdasarkan hasil penelitian uji koefisien determinasi menggunakan uji parsial, diperoleh hasil bahwa pemberian barang (X2) memiliki pengaruh siginfikan terhadap partisipasi politik (Y). hal ini dibuktikan bahwa dari nilai koefisien determinasi diketahui bawah $\mathrm{R}^{2}$ sebesar 0,52 yang artinya
$52 \%$ menunjukkan bahwa pemberian uang berpengaruh terhadap partisipasi politik pada pada pemilihan kepala daerah Kabupaten Wajo.

b) Pengaruh pemberian janji (X3) terhadap partisipasi politik (Y). Berdasarkan hasil penelitian uji koefisien determinasi menggunakan uji parsial, diperoleh hasil bahwa pemberian janji (X3) memiliki pengaruh siginfikan terhadap partisipasi politik (Y). hal ini dibuktikan bahwa dari nilai koefisien determinasi diketahui bawah $\mathrm{R}^{2}$ sebesar 0,06 yang artinya $6 \%$ menunjukkan bahwa pemberian uang berpengaruh terhadap partisipasi politik pada pada pemilihan kepala daerah Kabupaten Wajo.

\section{Pengaruh Secara Simultan Politik} Uang terhadap Partisipasi Politik pada Pemilihan Kepala Daerah Kabupaten Wajo.

Berdasarkan hasil analisis deskriptif terkait politik uang (X) dan partisipasi politik (Y), ditemukan bahwa pada variabel politik uang (X) yaitu pada indikator ke tiga yaitu pemberian mempengaruhi partisipasi politik masih ada sejumlah kecil responden pemilih pemula yang kurang setuju dengan beberapa kriteria terkait pemberian janji. Hal ini menunjukkan bahwa politik uang pada Pemilihan Kepala Daerah Kabupaten Wajo Tahun 2018 cukup mampu mempengaruhi partisipasi politik pemilih pemula.

Lebih lanjut, hasil penelitian menggunakan analisis secara simultan dapat ditemukan bahwa $\mathrm{R}^{2}$ sebesar 0,53 hal ini berarti $53 \%$ yang 
menunjukkan politik uang mempengaruhi partisipasi politik, dan sisanya dipengauhi oleh variabel lain yang belum diteliti dalam penelitian ini. hasil penelitian ini dtiemukan sama dengan penelitian terdahulu yang dilakukan Akbar Andi (2016), dalam penelitiannya yang berjudul "Pengaruh Money politics terhadap Partisipasi Masyarakat pada Pilkada 2015 di Kabupaten Bulukumba (Studi Kasus Desa Barugae Kec. Bulukumpa)". Hasil penelitian menunjukkan bahwa pengaruh money politics terhadap partisipasi masyarakat memang memberikan pengaruh yang cukup signifikan dimana mayoritas masyarakat Barugae yang menerima money politics turut berpartisipasi dalam pilkada walaupun dalam pemberian uang maupun barang tidak menjamin dalam menentukan pilihan masyarakat dalam memberikan suara kepada si pemberi.

\section{E. SIMPULAN DAN SARAN}

\section{Kesimpulan}

Berdasarkan hasil penelitian dan analsis data yang dilakukan serta pembahasan yang telah dikemukakan maka dapat disimpulkan sebagai berikut:

a) Berdasarkan hasil analisis deskriktif menunjukkan bahwa variabel politik uang (X) yang mencakup indikator pemberian uang, pemberian dan pemberian janji memperoleh hasil sebesar 2,89 dan masuk dalam kategori cukup berpengaruh. Selanjutnya, variabel partisipasi politik (Y) yang mencakup indikator pemberian hak suara, menghadiri rapat umum, menjadi anggota partai, dan mengadakan hubungan kontak pemerintah atau parlemen memperoleh hasil sebesar 2,78 dan masuk dalam kategori cukup baik.

b) Berdasarkan hasil analisis regresi secara parsial menunjukkan bahwa pemberian uang dan pemberian berpengaruh terhadap partisipasi politik, sedangkan pemberian janji tidak berpengaruh terhadap partisipasi politik pada Pemilihan Kepala Daerah Kabupaten Wajo Tahun 2018.

c) Berdasarkan hasil analisis regresi secara simultan atau kesuluruhan memperoleh hasil sebesar 53\% yang menunjukkan, bahwa variabel politik uang $(\mathrm{X})$ memiliki pengaruh yang signifikan terhadap partisipasi politik (Y) pada Pemilihan Kepala Daerah Kabupaten Wajo Tahun 2018.

\section{Saran}

Sistem demokrasi yang belum matang dijalankan seperti di Indonesia, politik uang (money politics) marak dijadikan sebagai alat untuk memobilisasikan dukungan. Dan hasil penelitian, ditemukan bahwa adanya kecenderungan antara pengaruh politik uang terhadap partisipasi pemilih pemula pada Pemilukada Tahun 2018. Praktik politik uang mengakibatkan lunturnya nilai-nilai demokrasi, mendelegitimasi dan mendistorsi pemilu, melemahkan akuntabilitas politik antara partai/candidat dan pemilih, melemahkan sistem kepartaian, dan menghadirkan pemimpin politik yang korup. 


\section{DAFTAR PUSTAKA}

Akbar, A. (2016). Pengaruh Money Politics terhadap partisipasi masyrakat Pada Pilkada 2015 di Kabupaten Bulukumba (Studi Kasus Desa Barugae Kec. Bulukumpa) (Doctoral dissertation, Universitas Islam Negeri Alauddin Makassar). Diakses pada tanggal 29 Maret 2020.

Budiardjo, M. (1998). Partisipasi dan Partai Politik, Edisi Revisi. Jakarta: Yayasan obor Indonesia.

Budiardjo, M. (2008). Dasar-Dasar Ilmu Politik. Jakarta (ID): PT Gramedia Pustaka Utama.

Fadjar, Muhkti. (2013). Pemilu, Perselisihan Hasil Pemilu, dan Demokrasi. Malang: Setara Pres.

Ismawan, Indra. (1999). Money Politics. Yogyakarta: Media Pressindo.

McClosky, H. (2008). Partisipasi Politik. Dalam P. M. Budiardjo, Dasar-Dasar Ilmu Politik. Jakarta: Pt Gramedia Pustaka Utama.

Undang-Undang No. 10 tahun 2008 tentang Pemilih Pemula.

Undang-Undang No. 7 tahun 2017 tentang Pemilu.

Unila__. Tinjauan Pustaka A. Tinjauan Tentang Perilaku Pemilih. (Online), (digilib.unila.ac.id, diakses pada tanggal 12 Agustus 2020).

Wajoterkini. 2018 KPU Giat Sosialisasi Pendidikan Pemilih. (Online), (wajoterkinini.com, diakses pada tanggal 9 agustus 2020). 